\section{Assessment of Freezing Injury in Palm Species by Chlorophyll Fluorescence}

\author{
María A. Equiza ${ }^{2}$ \\ Department of Renewable Resources, University of Alberta, 4-51 Earth \\ Sciences Building, Edmonton, Alberta T6G 2E3, Canada
}

David A. Francko ${ }^{1}$

Department of Botany, Miami University, Oxford, OH 45056

Additional index words. palms, freezing damage, chlorophyll fluorescence

\begin{abstract}
Freezing temperatures present major constraints for palm cultivation in temperate regions. As a result of their landscape value, there is a constant need for appropriate species and cultivars for freeze-prone areas. The objective of the present study was to evaluate the suitability of the chlorophyll fluorescence technique for quantitative assessment of freezing injury in palms. Five palm species known to differ in their freezing tolerance were selected: Copernicia alba, Washingtonia filifera, Sabal palmetto, Trachycarpus fortunei, and Rhapidophyllum hystrix. Leaf segments were frozen at $-5,-10,-15$, and $-20{ }^{\circ} \mathrm{C}$ for $1 \mathrm{~h}$. Repeated freezing-thawing cycles were additionally performed in young and older leaves of $R$. hystrix. Depending on the species and temperature, significant differences in the ratio of variable-to-maximal fluorescence $\left(F_{v} / F_{m}\right)$ were detected $3 \mathrm{~h}$ after the freezing treatment, whereas visual symptoms appeared after $24 \mathrm{~h}$. A strong positive correlation $\left(r^{2}=0.94\right)$ was found between the injury index calculated from $F_{v} / F_{m}$ values and the index of injury based on the electrolyte leakage technique. Although both indices provided similar information, the nondestructive chlorophyll fluorescence method allows monitoring the progression of damage as well as the eventual recovery taking place in the leaf tissue after freezing.
\end{abstract}

Freezing temperatures are one of the major constraints for palm cultivation in temperate regions. Severe cold damage can destroy plant tissues and may severely reduce water conduction in the stem (Larcher and Winter, 1981; Meerow, 2005). When warmer weather returns, plant pathogens often attack weakened plants through damaged tissue (Meerow, 2005). Despite difficulties of successfully growing palms in freeze-prone regions, their unique landscape value makes them a major horticultural asset. Therefore, there is a continuous search for suitable species and cultivars (Broschat and Meerow, 2000; Francko, 2003). A rapid and accurate quantitative assessment of freezing injury would facilitate the screening of putatively cold-hardy new cultivars and varieties. Comparative data on freezing tolerance of diverse palm species obtained under controlled laboratory condi-

Received for publication 12 Jan. 2010. Accepted for publication 8 Mar. 2010.

Support was provided by a grant from the Ohio Plant Biotechnology Consortium (400973).

We thank Dr. Alfredo Huerta (Miami University) for lending the OS5-FL pulse amplitude-modulated fluorometer and to Dr. Kenneth Wilson (Miami University) for his valuable insights on palm responses to freezing. Earlier versions of the manuscript were greatly improved by comments provided by Dr. Jorge Tognetti (Universidad Nacional de March del Plata) and Lic. Damián Cirelli (University of Alberta) as well as by three anonymous reviewers. ${ }^{1}$ Present address: Department of Biological Sciences, The University of Alabama, Tuscaloosa, AL 35487. ${ }^{2}$ To whom reprint requests should be addressed; e-mail ale.equiza@gmail.com. tions are scarce with the report of Larcher and Winter (1981) appearing to be the only one available.

Several methods have been developed to quantify freezing damage in plants. Visual assessment of injury, e.g., percentage of leaf decay, water-soaked patches, and/or necrotic areas, is somewhat subjective and symptoms might take time to appear (Francko and Wilson, 2004; Percival and Henderson, 2003). Vital staining such as triphenyl tetrazolium chloride (TTC) has not been effective in all species (Steponkus and Lanphear, 1967). We found that TTC was unreliable for assessment of freezing damage in several palm species as a result of inadequate infiltration of the TTC solution into the leaf tissue (Equiza and Francko, unpublished data). This problem might be related to the particular anatomical characteristics of palm leaves, e.g., thick-walled fibers and mesophyll cells with silica incrustations (Larcher et al., 1991; Martens et al., 1980).

The electrolyte leakage method (Dexter et al., 1932) has been extensively used to quantify plant tissue damage by frost. For quantitative comparisons among species, the "Index of Injury" developed by Flint et al. (1967) has been considered to be an accurate indicator of freezing tolerance in many species, including palms (Larcher and Winter, 1981). However, it also has some limitations because it is destructive as well as laborintensive and time-consuming.

More recently, chlorophyll fluorescence analysis has been used to evaluate plant responses to different environmental stresses (Baker and Rosenqvist, 2004; Maxwell and
Johnson, 2000). Chlorophyll fluorescence assesses the fate of excitation energy in the photosynthetic apparatus in a nondestructive manner. The technique has been shown to provide a rapid, sensitive, and reliable diagnosis of plant tolerance to freezing temperatures in several species (Binder and Fielder, 1996; Percival and Henderson, 2003; Rizza et al., 2001). Furthermore, screening of excised leaf material using the chlorophyll fluorescence technique has provided a useful system with which to rank freeze tolerance in whole plants (Brennan and Jefferies, 1990; Percival and Henderson, 2003). Despite the growing use of this technique, its feasibility to evaluate freezing injury in palm species has not yet been examined. The objectives of the present study are to evaluate whether the chlorophyll fluorescence technique can be used to characterize freezing sensitivity in different palm species and to compare its advantages/limitations in relation to the electrolyte leakage method.

\section{Materials and Methods}

Plant material. Five species of fan palms that differ widely in their freezing tolerance were selected for the study: Copernicia alba (caranday wax palm), Washingtonia filifera (California fan palm), Sabal palmetto (cabbage palm), Trachycarpus fortunei (Chinese windmill palm), and Rhapidophyllum hystrix (needle palm) (Table 1). Plants, which were 2 to 3 years old, were obtained from a commercial nursery (Gerry's Jungle, Neotropic Nursery, Scottsmoor, FL). Older specimens $(\approx 12$ years old) of $R$. hystrix were also used for comparison of freezing sensitivity in young, i.e., current year, and older leaves. Palms were grown in pots filled with peat:vermiculite:perlite (2:1:1 by volume) with controlledrelease fertilizer (Osmocote ${ }^{\circledR}$ NPK 19:6:12; The Scotts Company, Marysville, OH). Plants were kept in a greenhouse (Miami University, Oxford, $\mathrm{OH}$ ) under natural light and temperatures spanning 15 to $26^{\circ} \mathrm{C}$.

Freezing tests. Nine plants per species were used. The second youngest fully expanded fan leaf from each plant was cut for the freezing treatments. Five $10-\mathrm{cm}$ segments were obtained from different lobes within the leaf. Each segment was randomly assigned to a target temperature $(+4,-5,-10,-15$, and $-20{ }^{\circ} \mathrm{C}$ ). All segments were further cut in two 5 -cm subsegments to measure one by the chlorophyll fluorescence method and the other one by the electrolyte leakage method (Supplemental Fig. 1). This sampling methodology minimized potential differences in freezing tolerance resulting from leaf age, which has been shown to have a significant effect in palms (Larcher and Winter, 1981). In Rhapidophyllum hystrix, older leaves were also used in the freezing tests.

Each pair of subsegments was sprayed with ice water, enclosed inside a small plastic bag, and arranged horizontally inside an environmental chamber (Thermo Scientific Revco, Model BOD 50; Fisher Scientific, Inc., Ashville, NC) at $-1{ }^{\circ} \mathrm{C}$ for $1 \mathrm{~h}$. The temperature was then lowered $\left(\approx 2{ }^{\circ} \mathrm{C} / \mathrm{min}\right)$ to the selected 
targets. Temperatures were maintained within $\pm 0.5^{\circ} \mathrm{C}$ of the desired target as indicated by two digital thermometers with their probes situated one above and one below the shelf where samples were placed. Each target temperature was maintained for $1 \mathrm{~h}$. After the freezing treatment finished, samples were stored at room temperature in petri dishes with moist filter paper. Control leaf segments were kept in a refrigerator at $4{ }^{\circ} \mathrm{C}$ for the duration of the freezing treatment and they were afterward stored in the same manner as the freezing-treated samples.

Electrolyte leakage method. Five discs $\left(0.25 \mathrm{~cm}^{2}\right.$ each) were taken with a hole punch from each 5-cm subsegment. Discs were placed inside test tubes with $7 \mathrm{~mL}$ doubledistilled water, shaken for $10 \mathrm{~s}$, and left for $24 \mathrm{~h}$ on a laboratory bench at room temperature ( 20 to $22{ }^{\circ} \mathrm{C}$ ). After the incubation period, tubes were shaken again for $10 \mathrm{~s}$ and the electrical conductivity of the solution was measured with a Fisher Scientific Traceable Conductivity and TDS Meter (Fisher Scientific, Inc., Pittsburgh, PA) (accuracy $\pm 0.4 \%$ ). Conductivity was measured again $24 \mathrm{~h}$ after tubes were autoclaved at $121{ }^{\circ} \mathrm{C}, 15 \mathrm{psi}$, for $30 \mathrm{~min}$.

Conductivity values from frozen and unfrozen samples before and after being heatkilled were used to calculate the Index of Injury (I) developed by Flint et al. (1967):

$$
\begin{aligned}
\mathrm{I} & =100 *\left[\left(\mathrm{R}_{\mathrm{t}}-\mathrm{R}_{0}\right) /\left(1-\mathrm{R}_{0}\right)\right], \\
\mathrm{R}_{\mathrm{t}} & =\mathrm{L}_{\mathrm{t}} / \mathrm{L}_{\mathrm{k}} \text { and } \mathrm{R}_{0}=\mathrm{L}_{0} / \mathrm{L}_{\mathrm{d}} .
\end{aligned}
$$

in which $R_{t}=$ fractional release of electrolytes (frozen tissue), $\mathrm{R}_{0}=$ fractional release of

\begin{tabular}{|c|c|c|}
\hline Species & Origin $^{z}$ & $\begin{array}{l}\text { Reported freezing } \\
\text { tolerance }\end{array}$ \\
\hline $\begin{array}{l}\text { Copernicia alba } \\
\text { (caranday wax palm) }\end{array}$ & $\begin{array}{l}\text { West-central Brazil to } \\
\text { northeast Argentina }\end{array}$ & $\begin{array}{l}-3.8^{\circ} \mathrm{C}^{\mathrm{y}} \\
-3{ }^{\circ} \mathrm{C}^{\mathrm{x}}\end{array}$ \\
\hline $\begin{array}{l}\text { Washingtonia filifera } \\
\quad \text { (California fan palm) }\end{array}$ & $\begin{array}{l}\text { Southwest United States } \\
\text { and northwest Mexico }\end{array}$ & $\begin{array}{l}-12.2^{\circ} \mathrm{C}^{\mathrm{y}} \\
-6{ }^{\circ} \mathrm{C}(\text { seedling })^{\mathrm{w}} \\
\left.-10^{\circ} \mathrm{C} \text { (adult) }\right)^{\mathrm{w}}\end{array}$ \\
\hline $\begin{array}{l}\text { Sabal palmetto } \\
\quad \text { (cabbage palm) }\end{array}$ & $\begin{array}{l}\text { Southeast United States, } \\
\text { Cuba, and Bahamas }\end{array}$ & $-12.2^{\circ} \mathrm{C}^{\mathrm{y}}$ \\
\hline $\begin{array}{l}\text { Trachycarpus fortunei } \\
\quad \text { (windmill palm, chusan palm) }\end{array}$ & $\begin{array}{l}\text { Central China and } \\
\text { north Burma }\end{array}$ & $\begin{array}{l}-14.9^{\circ} \mathrm{C}^{\mathrm{y}} \\
-12^{\circ} \mathrm{C} \text { ( seedling) }{ }^{\mathrm{w}} \\
-14{ }^{\circ} \mathrm{C}(\text { adult })^{\mathrm{w}}\end{array}$ \\
\hline Rhapidophyllum hystrix & Southeast United States & $-20.5^{\circ} \mathrm{C}^{\mathrm{y}}$ \\
\hline
\end{tabular}

Table 1. Natural distribution and reported freezing tolerance of the selected palm species.

(needle palm)

${ }^{\text {zhttp://apps.kew.org/wcsp/. }}$

'http://davesgarden.com/guides/articles/view/470/.

xhttp://www.plantapalm.com/Vpe/horticulture/vpe_horticulture4.htm.

${ }^{\mathrm{w}}$ Larcher and Winter (1981).

electrolytes (unfrozen tissue), $\mathrm{L}_{\mathrm{t}}=$ leachate conductivity (frozen tissue), $\mathrm{L}_{0}=$ leachate conductivity (unfrozen tissue), $\mathrm{L}_{\mathrm{k}}=$ leachate conductivity (frozen tissue after being heatkilled), and $\mathrm{L}_{\mathrm{d}}=$ leachate conductivity (unfrozen sample after being heat-killed).

Chlorophyll fluorescence. The ratio of variable-to-maximal fluorescence $\left(\mathrm{F}_{\mathrm{v}} / \mathrm{F}_{\mathrm{m}}\right)$ was used to quantify the sensitivity of leaf tissue to freezing. $F_{v} / F_{m}$ represents the maximum quantum efficiency of photosystem II (Maxwell and Johnson, 2000). In a healthy leaf, $\mathrm{F}_{\mathrm{v}} / \mathrm{F}_{\mathrm{m}}$ is $\approx 0.8$ and a decrease in $\mathrm{F}_{\mathrm{v}} / \mathrm{F}_{\mathrm{m}}$ would indicate stress on the photosynthetic system (Maxwell and Johnson, 2000). $\mathrm{F}_{\mathrm{v}} / \mathrm{F}_{\mathrm{m}}$ is calculated as $\left(\mathrm{F}_{\mathrm{m}}-\mathrm{F}_{\mathrm{o}}\right) / \mathrm{F}_{\mathrm{m}}$, in which $\mathrm{F}_{\mathrm{o}}$ is the minimal fluorescence of a dark-adapted leaf and $F_{m}$ is the maximal fluorescence of the same leaf after application of a saturating flash (Maxwell and Johnson, 2000).

$\mathrm{F}_{\mathrm{v}} / \mathrm{F}_{\mathrm{m}}$ ratios were measured using a pulsemodulated fluorometer (OS5-FL; Opti-Sciences, Hudson, NH). Measurements were taken before preparing leaf samples for the freezing tests $(\mathrm{BF})$ and again $3 \mathrm{~h}$ and $24 \mathrm{~h}$ after they were removed from the freezer. Measurements were also taken in leaf segments kept in the refrigerator $\left(4^{\circ} \mathrm{C}\right)$ during the entire experiment. Using the $\mathrm{F}_{\mathrm{v}} / \mathrm{F}_{\mathrm{m}}$ values before (BF) and $24 \mathrm{~h}$ after the freezing treatment, we developed the following Injury Index $\left(\mathrm{I}_{\mathrm{chfl}}\right)$ :

$$
\mathrm{I}_{\mathrm{chfl}}=100 *\left[1-\left(\mathrm{F}_{\mathrm{v}} / \mathrm{F}_{\mathrm{m} 24 \mathrm{~h}} / \mathrm{F}_{\mathrm{v}} / \mathrm{F}_{\mathrm{mBF}}\right)\right] .
$$

Data analysis. Changes in $\mathrm{F}_{\mathrm{v}} / \mathrm{F}_{\mathrm{m}}$ values before and after the freezing treatment were analyzed using repeated-measures analysis of variance followed by the Tukey's honestly
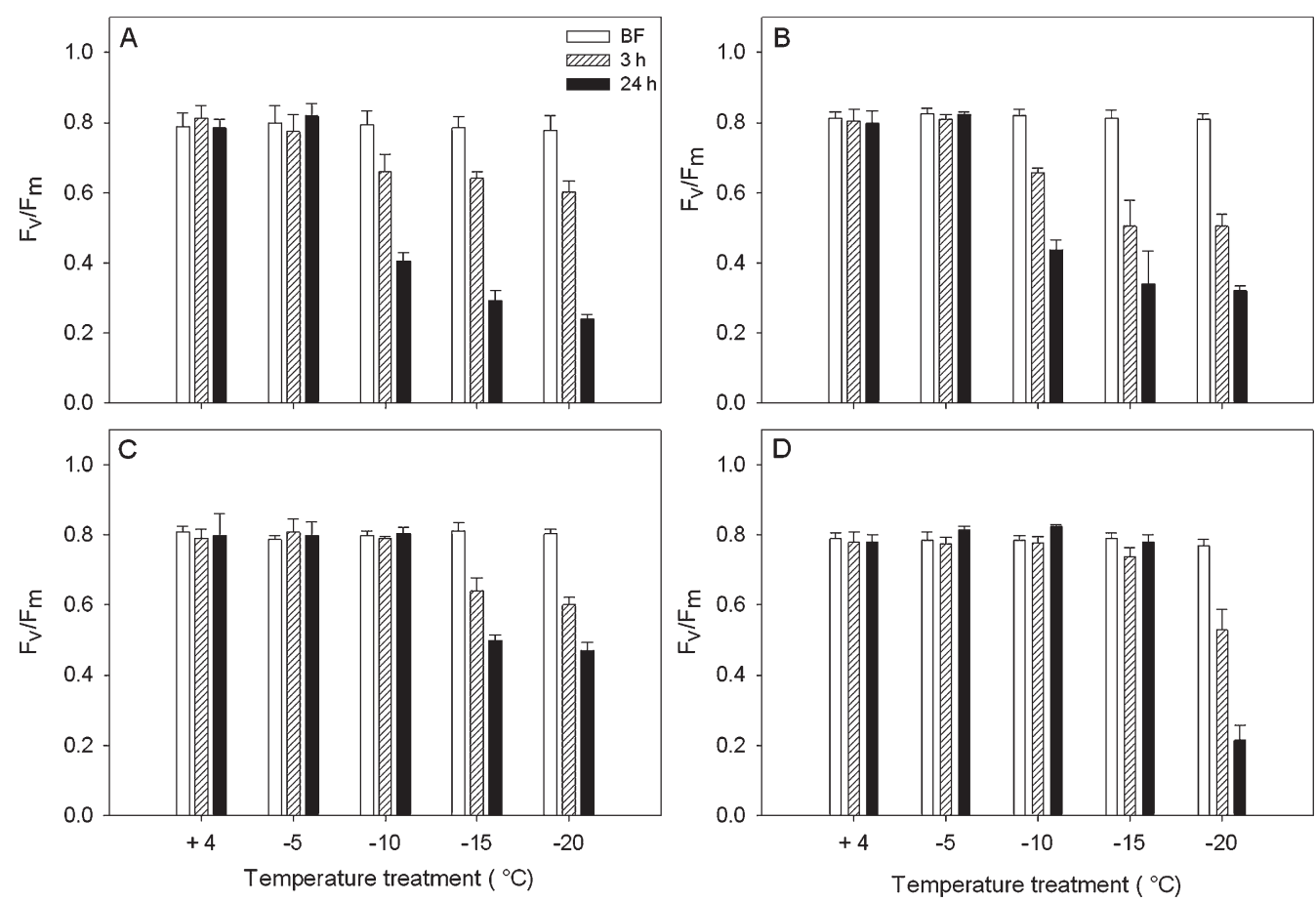

Fig. 1. Ratio of variable-to-maximal fluorescence $\left(\mathrm{F}_{\mathrm{v}} / \mathrm{F}_{\mathrm{m}}\right)$ values of leaf segments frozen to $-5,-10,-15$, or $-20{ }^{\circ} \mathrm{C}$ for $1 \mathrm{~h}$. Controls were kept in a refrigerator at $+4{ }^{\circ} \mathrm{C}$ for the duration of the freezing treatment. All samples were afterward stored at room temperature in petri dishes with moist filter paper. Measurements were taken before freezing (BF) and $3 \mathrm{~h}$ and $24 \mathrm{~h}$ after freezing. (A) Copernicia alba; (B) Washingtonia filifera; (C) Sabal palmetto; (D) Trachycarpus fortunei. Data are means of nine plants. Bars indicate SD. 

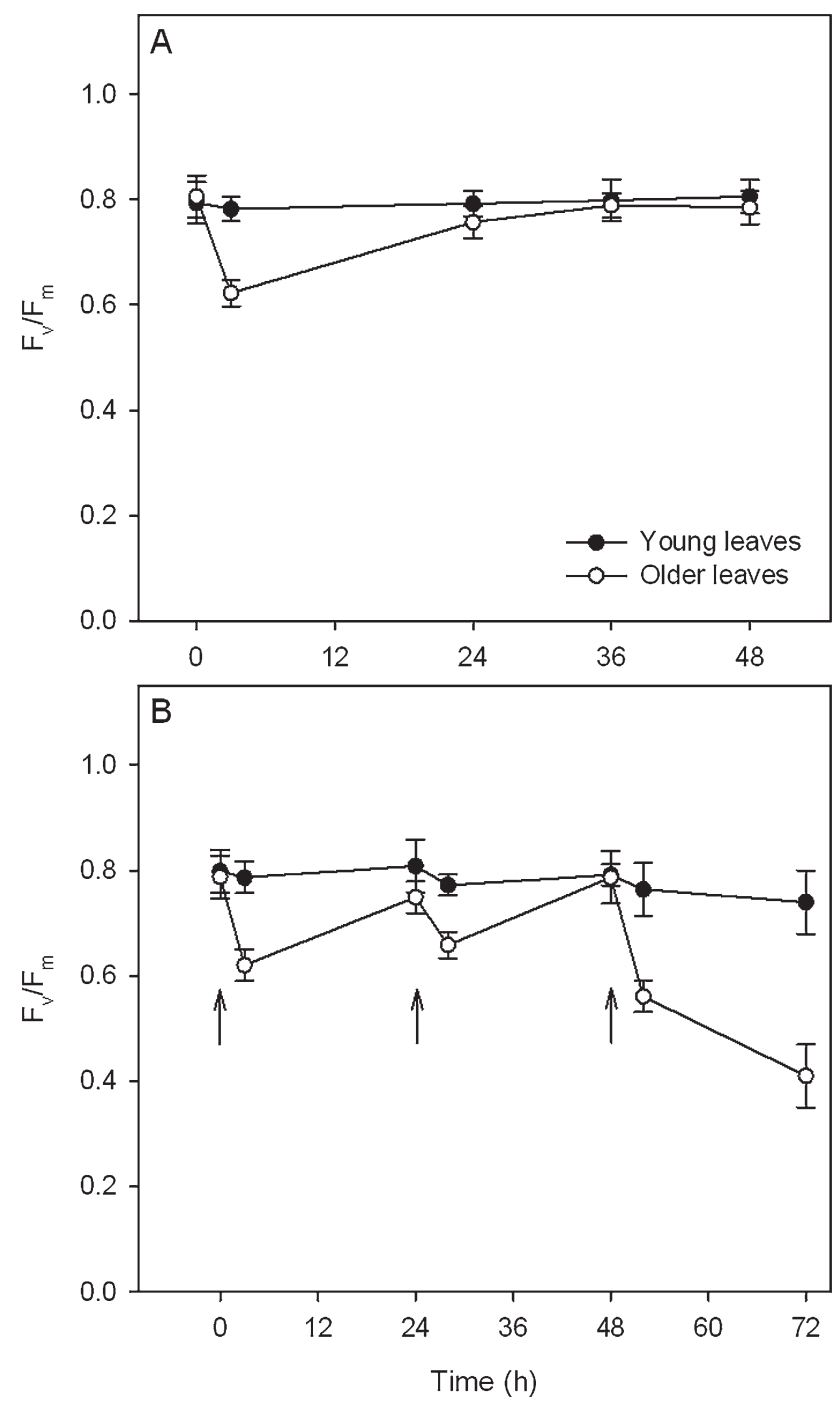

Fig. 2. (A) Ratio of variable-to-maximal fluorescence $\left(\mathrm{F}_{\mathrm{v}} / \mathrm{F}_{\mathrm{m}}\right)$ values of Rhapidophyllum hystrix leaf segments from young and older leaves frozen at $-20^{\circ} \mathrm{C}$ for $1 \mathrm{~h}$. Measurements were taken before freezing (BF) and $3 \mathrm{~h}$ and $24 \mathrm{~h}$ after freezing. (B) $\mathrm{F}_{\mathrm{v}} / \mathrm{F}_{\mathrm{m}}$ values of $R$. hystrix leaf segments from young and older leaves after repeated freezing $\left(-20^{\circ} \mathrm{C}\right.$, indicated by arrows) and thawing cycles. Data are means of nine plants. Bars indicate SD.

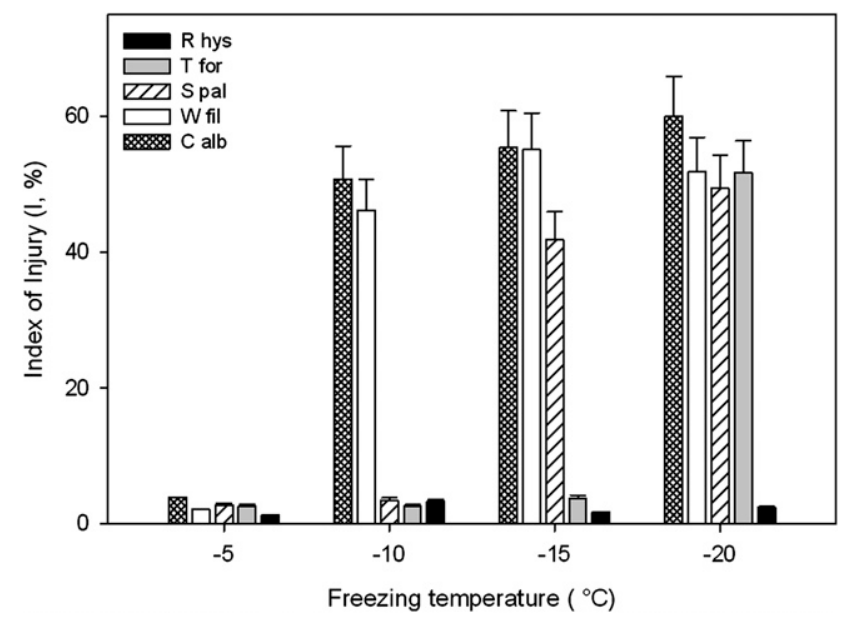

Fig. 3. Index of Injury (I), estimated by the electrolyte leakage method (Flint et al., 1967), of leaf samples subjected to $-5,-10,-15$, or $-20^{\circ} \mathrm{C}$ for $1 \mathrm{~h}$. Unfrozen samples, needed to calculate this index, were kept at $+4{ }^{\circ} \mathrm{C}$. Values are means of nine plants. Bars indicate SD. $\mathrm{C}$ alb $=$ Copernicia alba; $\mathrm{W}$ fil $=$ Washingtonia filifera $; \mathrm{S} \mathrm{pal}=$ Sabal palmetto $; \mathrm{T}$ for $=$ Trachycarpus fortunei $; \mathrm{R}$ hys $=$ Rhapidophyllum hystrix. significant differences test for mean separations $(\alpha=0.05)$ (SigmaPlot Version 11; Systat Software Inc., San Jose, CA). Correlation analysis was performed between the $\mathrm{I}_{\text {chfl }}$ we developed based on the chlorophyll fluorescence technique and the I developed by Flint et al. (1967) based on the electrolyte leakage method.

\section{Results and Discussion}

$\mathrm{F}_{\mathrm{v}} / \mathrm{F}_{\mathrm{m}}$ values before freezing ranged from 0.78 to 0.82 in all five species (Fig. 1), which is in agreement with the reported values commonly found in healthy plants (Maxwell and Johnson, 2000). Control leaf segments did not show any change in $\mathrm{F}_{\mathrm{v}} / \mathrm{F}_{\mathrm{m}}$ values after being stored $24 \mathrm{~h}$ in petri dishes with moist filter paper (Fig. 1), suggesting that no stress to the leaf segment occurred during storage and that any decline in $\mathrm{F}_{\mathrm{v}} / \mathrm{F}_{\mathrm{m}}$ values was attributable only to the freezing treatment.

No significant changes in $\mathrm{F}_{\mathrm{v}} / \mathrm{F}_{\mathrm{m}}$ values were found in leaf segments subjected to $-5{ }^{\circ} \mathrm{C}$ in any species (Fig. 1). Both Copernicia alba and Washingtonia filifera showed significant reductions in $\mathrm{F}_{\mathrm{v}} / \mathrm{F}_{\mathrm{m}}$ after being subjected to $-10{ }^{\circ} \mathrm{C}$, whereas Sabal palmetto showed reduced $\mathrm{F}_{\mathrm{v}} / \mathrm{F}_{\mathrm{m}}$ values at $-15{ }^{\circ} \mathrm{C}$ and Trachycarpus fortunei at $-20^{\circ} \mathrm{C}$ (Fig. 1A-D). The decline in $\mathrm{F}_{\mathrm{v}} / \mathrm{F}_{\mathrm{m}}$ values was already detected $3 \mathrm{~h}$ after the freezing treatment ended. A further drop was observed after $24 \mathrm{~h}$ (Fig. 1A-D), suggesting progressive damage within the leaf. In contrast to the early detection in $\mathrm{F}_{\mathrm{v}} / \mathrm{F}_{\mathrm{m}}$ changes, visual symptoms such as water-soaking areas appeared only after $24 \mathrm{~h}$. Thus, this technique was able to detect freezing damage in palm leaves when no visual symptoms were yet observed. Our data are in agreement with those of Binder and Fielder (1996) as well as Percival and Henderson (2003), who observed in different tree species that chlorophyll fluorescence could detect freezing damage before the appearance of any visible symptom.

An interesting differential response was observed between young and older leaves of Rhapidophyllum hystrix (needle palm). Young leaves did not show any change in $\mathrm{F}_{\mathrm{v}} / \mathrm{F}_{\mathrm{m}}$ values when frozen to $-20{ }^{\circ} \mathrm{C}$ (Fig. 2A). In contrast, older leaves did show a significant decline $(25 \%, P<0.001)$ after $3 \mathrm{~h}$, but $\mathrm{F}_{\mathrm{v}} / \mathrm{F}_{\mathrm{m}}$ values fully recovered after $24 \mathrm{~h}$ (Fig. 2A). Young leaves remained undamaged after being subjected to two additional freezing events (Fig. 2B), whereas older leaves showed another decline/recovery response after a second freezing and a steady decline after the third cycle (Fig. 2B). Rhapidophyllum hystrix has the largest known freezing tolerance among palms, reportedly surviving temperatures down to $-28{ }^{\circ} \mathrm{C}$ (Francko, 2003; Shuey and Wunderlin, 1977). This ability to withstand freezing has been shown to be associated with the maintenance of low supercooling points (Lokuge, 2006) and the expression of genes ( $\mathrm{Lu}, 2006)$ and proteins (Lokuge, 2006) related to cold tolerance. The response observed in our study suggests that a repair mechanism in older leaves might also be part of its ability to 


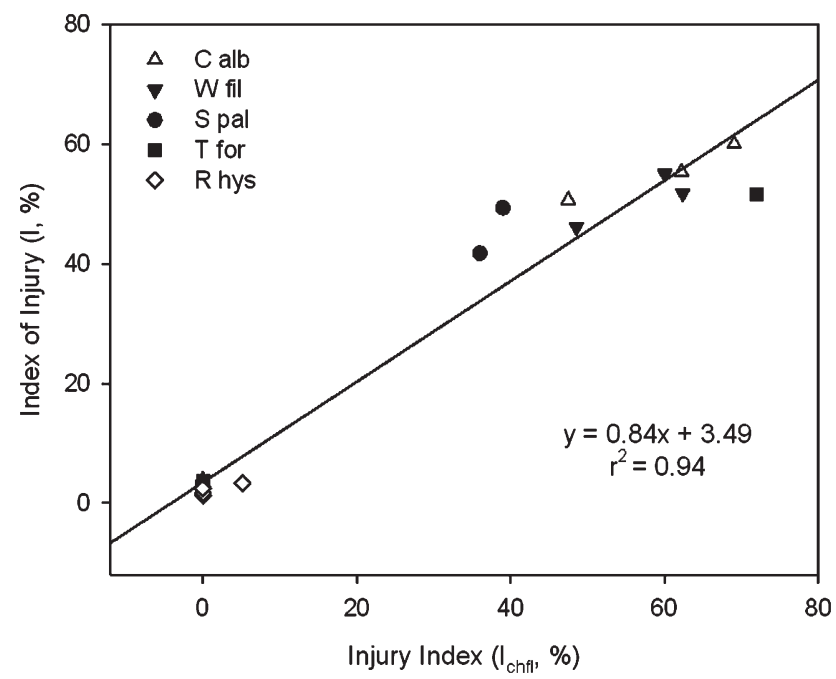

Fig. 4. Correlation between the Index of Injury (I) estimated from the electrolyte leakage method and the Injury Index $\left(\mathrm{I}_{\text {chff }}\right)$ calculated from ratio of variable-to-maximal fluorescence $\left(\mathrm{F}_{\mathrm{v}} / \mathrm{F}_{\mathrm{m}}\right)$ values of leaf samples before and $24 \mathrm{~h}$ after freezing. Values are means of nine plants.

survive low freezing temperatures. Such repair mechanism in older leaves might be an important part of the freezing-resistance strategy, because leaf span in this species is $\approx 6$ years (Clancy and Sullivan, 1990). Chlorophyll fluorescence appears as a promising technique to identify events at the physiological level that can be later explored at the cellular and molecular level with the ultimate goal of gaining a better understanding of the possible mechanisms associated with the differential freezing tolerance among palm species.

The index of injury estimated by the electrolyte leakage method ranked the species within the expected range of freezing sensitivity (Washingtonia filifera/Copernicia alba $>$ Sabal palmetto $>$ Trachycarpus fortunei $>$ Rhapidophyllum hystrix; Fig. 3). A positive correlation was found between this index and the one estimated by the chlorophyll fluorescence technique $\left(r^{2}=0.94\right.$; Fig. 4). Although both indices provided similar insights, the chlorophyll fluorescence method has some intrinsic advantages over the ion leakage method. Because it is nondestructive and noninvasive, it allows for periodic sampling and, thus, for monitoring the progression of damage and/or potential recovery taking place in the leaf. Future studies will include in situ assessment on intact leaves in whole plants.

\section{Literature Cited}

Baker, N.R. and E. Rosenqvist. 2004. Applications of chlorophyll fluorescence can improve crop production strategies: An examination of future possibilities. J. Expt. Bot. 55:1607-1621.

Binder, W.D. and P. Fielder. 1996. Chlorophyll fluorescence as an indicator of frost hardiness in white spruce seedlings from different latitudes. New For. 11:233-253.

Brennan, R.M. and R.A. Jefferies. 1990. The use of chlorophyll fluorescence in assessment of low temperature hardiness in blackcurrant (Ribes nigrum L.). Ann. Appl. Biol. 117:667-672.

Broschat, T.K. and A.W. Meerow. 2000. Ornamental palm horticulture. 1st Ed. University Press of Florida, Gainesville, FL.

Clancy, K.E. and M.J. Sullivan. 1990. Demography of the needle palm, Rhapidophyllum hystrix, in Mississippi and Alabama. Principes 34:6478.

Dexter, S.T., W.E. Tottingham, and L.F. Graber. 1932. Investigations of the hardiness of plants by measurement of electrical conductivity. Plant Physiol. 7:63-78.

Flint, H.L., B.R. Boyce, and D.J. Beattie. 1967. Index of injury-A useful expression of freezing injury to plant tissues as determined by the electrolytic method. Can. J. Plant Sci. 47:229-230.

Francko, D.A. 2003. Palms won't grow here and other myths. Warm-climate plants for cooler areas. 1st Ed. Timber Press, Portland, OR.

Francko, D.A. and K.G. Wilson. 2004. A new way to test for palm cold hardiness. Hardy Palms International 58:26-29.

Larcher, W., U. Meindl, E. Ralser, and M. Ishikawa. 1991. Persistent supercooling and silica deposition in cell walls of palm leaves. J. Plant Physiol. 139:146-154.

Larcher, W. and A. Winter. 1981. Frost susceptibility of palms: Experimental data and their interpretation. Principes 25:143-152.

Lokuge, M.A. 2006. Tissue culture, genetic transformation and cold tolerance mechanisms in cold-hardy palms. PhD diss., Miami University, Miami, FL.

Lu, L. 2006. Studies on cold resistance in palms: Analysis of Cbf-like genes. PhD diss., Miami University, Miami, FL.

Martens, J., N.W. Uhl, and L.H. Bailey. 1980 Methods for the study of leaf anatomy in palms. Biotech. Histochem. 55:241-246.

Maxwell, K. and G.N. Johnson. 2000. Chlorophyll fluorescence-A practical guide. J. Expt. Bot. 51:659-668.

Meerow, A.W. 2005. Betrock's cold hardy palms. 1 st Ed. Betrock Information System, Hollywood, FL.

Percival, G.C. and A. Henderson. 2003. An assessment of the freezing tolerance of urban trees using chlorophyll fluorescence. J. Hort. Sci. Biotechnol. 78:254-260.

Rizza, F., D. Pagani, A.M. Stanca, and L. Cattivelli. 2001. Use of chlorophyll fluorescence to evaluate the cold acclimation and freezing tolerance of winter and spring oats. Plant Breed. 120:389-396.

Shuey, A.G. and R.P. Wunderlin. 1977. The needle palm: Rhapidophyllum hystrix. Principes 21: $47-59$.

Steponkus, P.L. and F.O. Lanphear. 1967. Refinement of the triphenyl tetrazolium chloride method of determining cold injury. Plant Physiol. 42:1423-1426. 


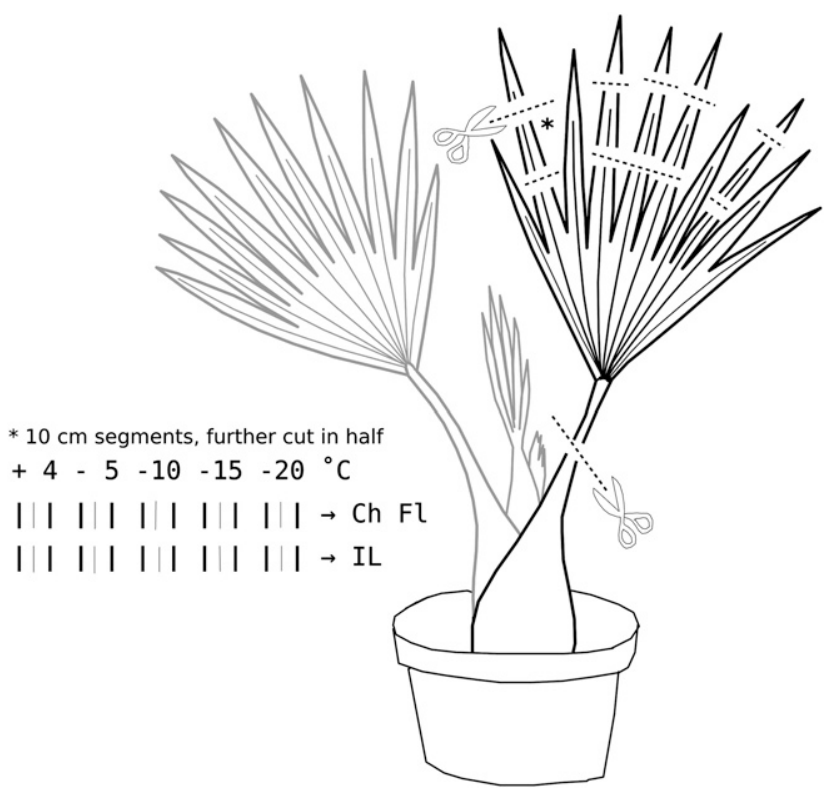

Supplemental Fig. 1. Sampling methodology. The second youngest fully expanded fan leaf from each plant (nine plants per species) was cut for the freezing treatments. Five 10-cm segments were obtained from different lobes within the leaf. Each segment was randomly assigned to a target temperature $(+4,-5$, $-10,-15$, and $-20^{\circ} \mathrm{C}$ ). All segments were further cut in half to measure one subsegment by the chlorophyll fluorescence method and the other one by the ion leakage method. This sampling methodology minimized potential differences in freezing tolerance resulting from leaf age, which has been shown to have a significant effect in palms (Larcher and Winter, 1981). 